observed was a pallor of the mucosa in the angles of the lip. A few days later superficial fissures developed exactly in the angle of the mouth. These lesions were covered with a honey-coloured crust which could be scraped off without causing bleeding. The lips became abnormally red and shiny, and the tongue a purplish red. In addition, a fine scaly desquamation appeared about the nose and ears. The ocular lesions were equally marked. The cornea appeared inflamed, due to its invasion by capillaries. This condition was followed by corneal opacity. Patients complained of itching and burning of the eyes, a hyper-sensitivity to light, and eye fatigue.

These symptoms comprise the clinical picture known as ariboflavinosis. Dr. Sebrell has found it very prevalent among people who are not economically restricted to a poor diet. In fact, he stated, without the inclusion of liberal amounts of milk, liver and eggs, it is difficult to select a diet adequate in riboflavin.

In the case of human subjects, clinical experience has demonstrated that vitamin deficiencies are usually mixed, rather than simple, and that the administration of all the vitamins together produces more rapid and complete cures than does treatment with any single vitamin. This phase of vitamin therapy was emphasized by Dr. Tom Spies. He reported a study of "twenty-five malnourished patients with mild pellagra, beriberi or riboflavin deficiency who were becoming worse in spite of bed rest and were refusing the diet offered them. They were given a mixture of brewers' yeast powder ( 25 per cent), peanut butter ( 67 per cent) and peanut oil ( 8 per cent). All except two patients ate it twice a day, and all of them improved gradually." Because such a mixture is a rich source of the natural vitamins of the B complex, as well as of protein, fat, carbohydrate and mineral salts, he suggested the popularization of a sandwich of whole wheat or high vitamin bread, combined with this peanut butter - dried yeast spread as a most effective preventive or therapeutic measure.

The efficacy of vitamin $\mathrm{K}$ in preventing bleeding in patients with a low prothrombin concentration in the blood was reported by Drs. Harry Smith and Emory D. Warner. Hæmorrhages due to failure of the blood to clot occur in both mother and child at child-birth, in obstructive jaundice, in chronic intestinal disorders and in bile duct tumours. This failure to clot is due to the inability of the body to produce enough prothrombin. Vitamin $K$ is an essential factor in the production of prothrombin. It is effective administered orally.

Drs. Smith and Warner recommended the inclusion of green vegetables, especially spinach, kale and tomatoes, in the diets of mothers during the last month of pregnancy, and the feeding of cow's milk to infants during the first three days of life to provide the necessary vitamin $\mathrm{K}$ during this critical period.

The most recently separated vitamins, pyridoxin and pantothenic acid, are already being studied clinically. Although a pyridoxin deficiency has not been described as a definite entity, the vitamin is believed to function in muscle metabolism. It was reported to cause improvement in patients having muscular weakness or suffering from Parkinson's disease. Here, again, administration with or after thiamin and nicotinic acid produces better results than when pyridoxin is given alone.

Pantothenic acid has been found in human blood. Dr. Edgar S. Gordon, of the University of Wisconsin, stated that very little is known as yet of its possible functions or of its clinical value. Spies and his co-workers found that the injection of pantothenic acid was followed by a rise in the ribofiavin content of the blood. He believes that this vitamin is also essential in human nutrition, and that it is associated in its action with riboflavin.

\title{
LABOUR CONDITIONS IN WEST AFRICA
}

\section{By F. W. H. Migeod}

$F_{1}$ OR countless centuries Africa had supplied labour to Eastern countries. When the American continent was discovered, an immediate demand arose for African labour for its plantations and industries. Eventually the slave trade came to an end, and Africa turned to developing the export of its own products, chiefly forestal. Progress after the change-over was slow at first. At the opening of the present century, however, mining was already well established, and planta- tions were started to extend the growth of economic products and secure a higher standard of quality. There ensued an increasing demand for paid labour. Nevertheless, in West Africa, the collection and preparation of forest products was still carried on by the natives in their own villages, as it still is. They traded their loads at the nearest store, or the one that offered best terms, and what they received for it was shared out between the members of the family concerned. 
Labour in tropical Africa implies rather a different thing from what is understood by 'labour' in Great Britain at the present day. The native tribal organization has usually consisted of a ruling class with the rest of the population slaves, or at least dependants. Merging with the ruling class was general ; and another stratum of slave population might be added below as the result of a successful war. Agriculture, the principal industry, was therefore based on slavery. On slave labour the tribe supported itself, and had a small balance of material or, in default, human goods to export. Some tribes kept no slaves ; they were cannibals. Some remote hill tribes or swamp tribes may also be exceptions.

When, therefore, the European colonies or protectorates became established, the Government readily obtained the labour it required by calling on the chiefs to furnish so many men for some definite work'such as building stations, making roads, railway construction, etc. The labourers would be paid if the work were beyond the chief's confines; within his own country he was responsible for it, and a money gift would usually be made to him in compensation. The Government was only concerned with the labour supplied being kept up to the number specified. Welfare conditions scarcely entered in. The labour largely looked after itself. As a result, however, of the opening up of the country to private enterprise, apart from trading, new conditions had to be met.

This is the background which it is useful to bear in mind when reading the able and valuable report by Major G. St. J. Orde Browne, labour adviser to the Secretary of State for the Colonies, presented to Parliament in May of this year*. Each of the West African Colonies, Nigeria (with British Cameroons), Gold Coast, Sierra Leone and Gambia is studied separately, and roughly the first quarter of the pamphlet contains a summary of observations and recommendations. Major Orde Browne has had long labour experience in East Africa, and in his five months in West Africa in the dry season of 1939-40 he was able by means of extensive and rapid travel to probe into labour conditions in all these colonies.

The welfare of the labourer was his first consideration. The number of instances in which he could find nothing to recommend is testimony to the generally satisfactory. labour position of West Africa. It is mostly in the big Europeanized towns where improvements are called for.

It has already been said that labour questions in Africa, and more particularly in West Africa, cannot be treated in the same way as in Great

\footnotetext{
* Labour Conditions in West Africa. Report by Major G. St. J. Orde Browne. (Cmd. 6277.) Pp. 149. (London: H.M. Stationery Offlee, 1941.) 28. 6d. net.
}

Britain. The great majority of the natives are attached to the soil. This means that everyone has a home to return to whether he be of free or servile origin. He can come out periodically to work for hire, and when he has earned what he considers enough to go back home with, he departs and resumes his agricultural life. He is free so far as his wage-earning is concerned to take it up or not, just as he pleases. Where this general statement does not apply is in the large towns, where a mixed population has collected which has lost touch with home life, and either cannot, on account of distance, or for some other reason does not desire to, return to the place of their birth. Perhaps it is because he is a seasonal worker that he does not like being interfered with even for his own good, a fact Major Orde Browne refers to more than once. $\mathrm{He}$ has come to gain money, and will put up with inconveniences to do so. The local abundance of food is a major factor in the ehoice of his place of work. Often food weighs more in this choice than the actual wages paid.

This report discusses food problems very fully. The view has grown up in recent years in Great Britain that the African is generally undernourished. He used not to be. If undernourishment does exist at all widely, it is a result of economic development of the country, food-growing being subordinated to the production of sale crops or of mechanized industry. Without going deeper into the matter, it may be observed that large markets, such as are especially common in Nigeria, go a long way towards stimulating the growth and equally important distribution of food.

The migratory type of labour, that is the seasonal workers, have in some cases long distances to travel. Usually, however, they know exactly where they intend or hope to work, and travel in parties, some members of which have been over the ground before. There are, of course, cases in which some of the party fall out by the way, and one rather gets the impression from this report of large numbers of would-be labourers arriving at their journey's end worn out with the march and suffering from exhaustion from want of food. Such cases may occur. In any event, rest camps set up by the Government on the main routes are a great boon to the travellers. The mere walk of a few hundred miles is nothing very serious of itself. One has done it oneself. They are not entirely without ideas of food-provision for the journey; and food will be supplemented with saleable goods. In many cases the women go too.

Housing is a subject the migratory labourer is not too greatly concerned with. So long as he has somewhere to spread his mat, and the householder will look after his few personal belongings, he is satisfied. Except when actually asleep the house 
is scarcely wanted. He especially does not like a draught, having few clothes on indoors; and so concrete houses with tin roofs do not meet with his approval. The hygienic house is not necessarily the most comfortable. However, judging by this report, living conditions in general are good on all the old-established plantations, and are equally so on the mines. Where overcrowding and bad living conditions do apply is in the towns or in the villages surrounding an industrial area; and it is with this very difficult problem that the Medical and Sanitary Department has to cope Here, too, police problems are equally acute.

All the difficulties, however, in connexion with the labourers who come and do eventually go home, are small compared with the problems of those who do not go, either from illness or some other cause. Only too many of them unable to do regular work turn to crime. They spend their money as they receive it, and when that has become an acquired habit they will in fact never return home. There are many such. They form the body of floating labour, and it is mainly on their account that such reports as Major Orde Browne's are written.

Skilled labour figures equally largely in this report. Such labour is a product of education in some form or other. That may be either apprenticeship in the workshop, or a course of training in Government technical schools. Both systems have their values, and it is debatable whether the youth who has, say, had his training in railway workshops with a certain amount of rough-andready treatment, is not better equipped than one who has led a very different life in a residential college, with amenities that render him less willing to undertake any sort of work. Urbanization is, of course, a necessary preliminary to the raising of a large body of skilled artisans, and those persons necessarily become detribalized and merge into the permanent population of the large towns. The report stresses the need for more and still more technical training; and the future of the colonies would seem to lie in a good supply of all sorts of technicians being turned out.

The early trend of education was the production of clerks. Every bright youth at school wanted, and still wants, to become a clerk and wear good European clothes and not do manual work. So associated is manual labour with inferiority of social status (and not in Africa alone), and indeed with old slavery memories, that no native considered he had improved his position unless he adopted the clerical or teaching or some similar profession.

All efforts of the Government to restrict the output of persons trained as clerks have been very largely neutralized by this ambition. When clerkships are, even in their lower grades, better paid than skilled mechanics in their higher grades, and really large salaries can still further be obtained either in the Government service or in trade or the professions, it is not surprising that the youth of the country desires training for the most lucrative work; and their parents share these views. Girls qualify to be telephone operators, shop assistants, etc., but only to a small extent, as the vast body of African opinion still considers the place of the woman is in the home.

For the welfare of labour, Major Orde Browne makes many valuable suggestions, as would only be expected from a man of his experience and qualifications. There is one qualification, however, which one is not sure that he has. One doubts if Major Orde Browne has ever handled labour personally; whether he has ever had to get his labour together for some enterprise, to work it to the utmost, and yet keep it and maintain his employment at such a level of attractiveness that he is never short; also whether he has personally experienced all those repetitions of exasperation and anxiety that success in keeping his own end up implies. The trend of colonial legislation has been to reduce penalties on delinquent labour and increase them for employers; but Major Orde Browne does point out that the latter have in cases been overdone. Unless there are would-be employers with capital entering a colony, there can be no wage-earning; and because a labourer has innocence on his face it does not follow there is innocence in his heart. Trade unionism has been imposed on the colonies from Great Britain. It applies less to the seasonal worker than to the urbanized population. Since, however, in all towns natives of different tribes normally congregate together, and have a titular chief of their own tribe to watch over their interests, the necessity for trade unionism, if any exist, is limited to detribalized natives. In some pages of this report it seems as if there are two persons speaking. One is Major Orde Browne, the experienced African official; the other is someone else who has adapted himself to trade unionism and British labour ideals.

Of the numerous recommendations made, many are expensive. The report was made on conditions prevailing in the earlier period of the War. With the subsequent cessation or limitation of external trade in West Africa, it may be doubted if any more than a small proportion of the recommendations can be put into force. Indeed the necessity for many of them may have lapsed. The best thing the native can do now would seem to be to revert to his former life on his farm and, growing enough food for his family, await a time when industrial and trading activities can be profitable. 